\title{
Arabic Language Phoneme Pronunciation Difficulties Among Upper Basic Hausa-Speaking Students in Kano State, Nigeria
}

\author{
Musa Siddiq Abdullahi \\ Department of Arts Education, \\ Faculty of Education, University of Ilorin, \\ Ilorin, Nigeria \\ abdullahi.ma@unilorin.edu.ng
}

\author{
Musa Salisu \\ Department of Arts Education, \\ Faculty of Education, University of Ilorin, \\ Ilorin, Nigeria \\ salisumusa95@yahoo.com
}

\begin{abstract}
In the process of learning a foreign language, there are some indispensable learning problems, especially in the pronunciation aspect. Therefore, this study investigated Arabic Language phoneme pronunciation difficulties among Upper Basic Hausa-speaking Arabic Language students in Kano State, Nigeria. The total population for the study was all Upper Basic Hausaspeaking students of Arabic in Kano State, Nigeria. Two hundred (200) Hausa-speaking Arabic students were sampled from the 3 senatorial districts in the state involving 9 Local Government Areas using multistage sampling procedure. A Pronunciation Test adapted from Adebayo (2010) with a reliability coefficient of 0.75 was used for data collection. Only 180 Pronunciation test that were properly filled and returned were subjected to both descriptive and inferential statistical analysis. The percentage was used to answer the research questions while Chi-square was employed to test the hypotheses postulated at the 0.05 level of significance. The findings of this study revealed that a number of Arabic consonants constitute pronunciation difficulty for the students due to the presence of their corresponding consonant sounds in Hausa language, while all Arabic vowels did not constitute much pronunciation difficulty for students. The findings also revealed that there was no significant difference in the Arabic consonant and vowel sounds that constitute pronunciation difficulties for male and female Upper Basic Hausaspeaking students of Arabic from both public and private schools in Kano State. In the light of these findings, it was recommended among others that, teachers of Arabic language should pay more attention to the various Arabic consonant and vowel phonemes as well as the Arabic syllable patterns that constitute pronunciation difficulties for the Hausa-speaking students of Arabic. The attention of Hausa-speaking students of Arabic should also be drawn to the semantic implications of phonemic replacement, reduction or prolongation.
\end{abstract}

Keywords: Arabic language, consonants, vowels, phoneme, Hausa-speaking students 


\section{INTRODUCTION}

Education as the bedrock of any developing nation is considered an instrument per excellence for achieving national development. This is in line with the National Policy on Education in Nigeria which stipulated that the educational goals of the country shall be set out in terms of their relevance to the needs of the individuals of the society and in consonance with the realities of our environment and the modern world (FRN, $2004 \& 2013)$.

Arabic as one of the recognised languages in the world is a native and an official language to 25 countries in Africa and Asia. Apart from being a language of communication like every other language, it is the language of the Holy Qur'an on which every Muslim relies (Abdelali, 2003). Qur'an is written in Arabic and all other Islamic terms are in Arabic; and millions of Muslims (both Arabs and non-Arabs) study the language. Arabic is taught worldwide in elementary and secondary schools, especially in Muslim schools. Universities around the world have classes that teach Arabic as one of their foreign languages. It is a tool for political and diplomatic interactions within international organisations such as the United Nations (U.N.), the African Union (A.U.) and the Organization of Petroleum Exporting Countries (O.P.E.C.) among others (Oladosu, 1992).

Arabic is spoken as a mother tongue by a Nigerian ethnic group called Shuwa Arab in the North Eastern part of Borno State (Oladosu, 2002); the language is also spoken as a second language by Nigerian Muslims who have basic orientation in Islamic education. It is also taken as a foreign language by a few non-Muslim citizens of the country (Oladosu, 2002). The language has conveniently found its way into two of the three major Nigerian languages (Hausa and Yoruba), where a reasonable percentage of these languages' lexical items are Arabic loan words. Since language is a cultural tool, some aspects of the Hausa and Yoruba cultures have cultural been influenced by Arab cultures. Consequently, the local, national, continental and international relevance of Arabic makes it a language of study at the primary, secondary and tertiary educational levels in Nigeria. Several Nigerian Colleges of Education offer Arabic education as a course of study, while some offer degrees in Arabic language in affiliation with some Nigerian universities.

Speaking is an important language skill. When people claim they are users of a particular language, they think they can speak the language and, by implication, they understand the language when spoken to. Pronunciation is an important component not only of learning a language, but also of using that language. Pronunciation is the manner in which speech sounds, especially connected sequences, are articulated by individual speakers or speakers generally (Trask, 1996). In other words, pronunciation is an umbrella word that encompasses the interrelated areas of sounds, phonetic symbols, stress, intonation, and rhythm.

Phoneme is any of the perceptually distinct unit of sound of a specified language that distinguished one word from another. In linguistics, it is a smallest unit of speech distinguishing one word (or word element) from another and the smallest unit of sound in a word that makes a difference in its pronunciation, as well as its meaning (Macmillan Dictionary, 2007). 
Awagona, Wolff and Löhr (2009) submitted that Hausa is one of the major Lingua Franca in some parts of West and Central Africa. It is spoken by up to 50 million speakers, and about half of these speakers use Hausa as their mother tongue. In Northern Nigeria alone, the language is spoken by over 18.5 million people (University of California Consortium for Language Learning and Teaching [ULC] Language Material Project, 2010). The Hausa speaking people can be said to be the major inhabitants of Nigeria's northern states with their concentration in Kano, Kaduna, and Sokoto States (N.Y.S.C. Directorate HQ, 1986). The Kano variety of Hausa is considered to be the standard Hausa dialect, and it is the form upon which written Hausa is based (ULC Language Material Project, 2010). L2 learners strive hard to attain native-like fluency; they never like to be distinguishable from the native speakers of such language, but pronunciation remains an obstacle (Al-Saidat, 2010). Pronunciation of the foreign language vocabulary appears to be one of the most remarkable difficulties as stressed by Senel (2006). Abdallah (2005) realised that learners of Arabic as a foreign language face many difficulties in pronouncing certain sounds especially those which do not exist in their mother tongue. Similarly, the Hausa-speaking students of Arabic face the same form of difficulties.

Arabic language has 28 consonant sounds, 3 short vowels, 3 long vowels and 2 diphthongs (Al-Janariy, 2008). In Arabic Language, consonants stand directly for their phonetic sounds. In the language, each letter, especially consonants, has one distinct way of pronunciation, no letter will change the sound associated with it in any place of the word, which is why most Arab linguists do not find any difference between "letter" and "sound" and that is why they refer to the latter using the former. In very rare cases, a three-letter sound will behave differently, and these are called the diseased letters in Arabic. Modern linguists call them "double agents" (Abdallah, 2005). The description of Arabic sounds is as follows:

Arabic Consonant Phonemes: There are 28 consonant phonemes in Arabic language

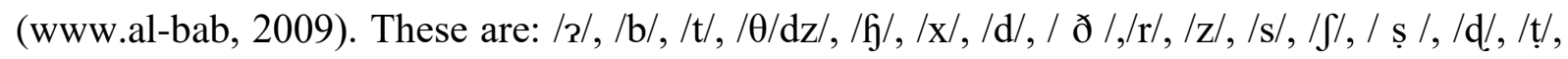
$/ \delta /, / \varsigma /, / \mathrm{V} /, / \mathrm{f} /, / \mathrm{q} /, / \mathrm{k} /, / \mathrm{l} /, / \mathrm{m} /, / \mathrm{n} /, / \mathrm{h} /, / \mathrm{w} /$ and $/ \mathrm{j} /$.

$\begin{array}{llllllll}\text { Short Vowels } & - & \text { fatha } & \mathrm{a} & / \mathrm{a} / & \text { as in } & \dot{\varphi} & b a \\ & - & \text { dumma } & \mathrm{u} & / \mathrm{u} / & \text { as in } & \varphi & b u \\ & - & \text { kasra } & \mathrm{i} & / \mathrm{i} / & \text { as in } & \varphi & b i\end{array}$

\begin{tabular}{|c|c|c|c|c|}
\hline Long Vowels & (Fully vocalized text & Name & Trans. & Value \\
\hline & $\overline{\mathrm{I}} \bar{\varnothing}$ & fatha + alif $(l)$ & $\bar{a}$ & /aa / \\
\hline & ळ & fatha + alif maqsura (تَى) & $\bar{a} / \mathrm{ay}$ & /aa/ \\
\hline & 9 & dumma + wāw & $\overline{\mathrm{u}} / \mathrm{uw}(\stackrel{s}{)})$ & / uu / \\
\hline & ه ي & kasra + yā & i/iy (-) & /ii / \\
\hline
\end{tabular}

Arabic vowels are indicated by diacritic marks placed above or below the consonant letters as demonstrated above. In everyday life, when writing Arabic, long vowels are usually written while, short ones are omitted. However, in the education system and particularly in Arabic Grammar classes, these vowels are clearly indicated since they are crucial to the syntax and the semantics of the language. An Arabic sentence can have a completely different meaning by a subtle change of the vowels. This is why in an important text such as the Qur'an, the vowels are mandatorily reflected. Children's books, elementary-school texts, and Arabic-language 
grammar text in general, will include diacritics to some degree. These are known as "vocalized" texts (UCL 2010).

A number of studies have been conducted on pronunciation difficulties faced by students. Al-Janariy (2008) carried out an analytical study of phonetic errors in Qur'anic recitation of some selected university students of Nigeria (in Arabic), while Oladosu (1993) studied pronunciation problems among pupils of traditional Quranic schools in Yoruba-land. Furthermore, Hamza (1998) studied the phonological problems facing students of Arabic in West Africa (in Arabic) just as Yusuf (1980) examined the phonetic problems faced by Hausa students of Arabic. In the same vein, Kamaru, Muhammed, Nik and Zamri (2009) investigated gender and use of Arabic language learning strategies while Adebayo (2010) studied the pronunciation problems among Junior Secondary School Yoruba-speaking students of Arabic.

\section{Statement of the Problem}

In the process of learning any foreign language like Arabic, there are always some indispensable learning problems which, if encountered, must be studied and solved to ensure mastery of the language. It has been observed that one of the major problems of second language (L2) learners is "pronunciation". L2 learners strive hard to attain native-like fluency; they never like to be distinguishable from the native speakers of such language, but pronunciation remains an obstacle. Thus, this study was designed to find out the types of pronunciation difficulties faced by Upper Basic students of Arabic in Kano State. Such a study is relevant because wrong pronunciations render communication unintelligible. Hence, this study is considered suitable in Kano State which has a total number of 683 secondary schools some of which offer Arabic as a school subject (Badamasi, 2012).

\section{Research Purpose and Questions}

The purpose of this study was to investigate Arabic Language phoneme pronunciation difficulties among upper-basic Hausa-speaking students in Kano State, Nigeria. Specifically, the study identified Arabic consonant sounds that constitute pronunciation difficulty for Upper Basic Hausa-speaking students of Arabic Language in Kano State, Nigeria; Arabic vowel sounds that constitute pronunciation difficulty for Upper Basic Hausa-speaking students of Arabic Language in Kano State; compared Arabic consonant sounds that constitute pronunciation difficult for male and female Upper Basic Hausa-speaking students of Arabic Language in Kano State; compared Arabic vowel sounds that constitute pronunciation difficulty for male and female Upper Basic Hausa-speaking students of Arabic language in Kano State; compared the Arabic consonant sounds that constitute pronunciation difficulty for Upper Basic Hausa-speaking students of Arabic Language in public and private schools in Kano State; compared the Arabic vowel sounds that constitute pronunciation difficulty for Upper Basic Hausa-speaking students of Arabic Language in public and private schools in Kano State. 
Therefore, the research questions answered were: "What are the Arabic consonant sounds that constitute pronunciation difficulty for Upper Basic Hausa-speaking students of Arabic Language in Kano State, Nigeria? What are the Arabic vowel sounds that constitute pronunciation difficulty for Upper Basic Hausa-speaking students of Arabic Language in Kano State? Is there any difference in the Arabic consonant sounds that constitute pronunciation difficulty for male and female Upper Basic Hausa-speaking students of Arabic Language in Kano State? Is there any difference in the Arabic vowel sounds that constitute pronunciation difficulty for male and female Upper Basic Hausa-speaking students of Arabic Language in Kano State? Is there any difference in the Arabic consonant sounds that constitute pronunciation difficulty for Upper Basic Hausa-speaking students of Arabic Language in public and private schools in Kano State? Is there any difference in the Arabic vowel sounds that constitute pronunciation difficulty for Upper Basic Hausa-speaking students of Arabic Language in public and private schools in Kano State?

\section{Research Limitation}

This study covered upper-basic Hausa-speaking students of Arabic Language in Kano State, Nigeria. Hence, the study is limited in geographical, sample and statistical scope. Further studies could therefore be conducted using a larger geographical and sample size with more robust statistical techniques to enhance the generalisability of the findings.

\section{Research Hypotheses}

The following hypotheses were postulated and tested:

Ho1: There is no significant difference in the Arabic consonant sounds that constitute pronunciation difficulty for male and female Upper Basic Hausa-speaking students of Arabic Language in Kano State.

Ho2: There is no significant difference in the Arabic vowel sounds that constitute pronunciation difficulty for male and female Upper Basic Hausa-speaking students of Arabic Language in Kano State.

Ho3: There is no significant difference in the Arabic consonant sounds that constitute pronunciation difficulty for Upper Basic Hausa-speaking students of Arabic Language in public and private basic schools in Kano State.

Ho4: There is no significant difference in the Arabic vowel sounds that constitute pronunciation difficulty for Upper Basic Hausa-speaking students of Arabic Language in public and private basic schools in Kano State. 


\section{METHODOLOGY}

\section{Research Type}

This study adopted a descriptive survey method. This was considered appropriate by the researchers to give a systematic description of the Arabic Language phoneme pronunciation difficulties among upper basic Hausa-speaking students of Arabic Language in Kano State, Nigeria.

\section{Instrument}

A modified pronunciation test from Adebayo (2010) titled "Arabic Language Phoneme Pronunciation Difficulties Performance Test" was used in this study. The performance test comprised two sections: A and B. Section A elicited information on the bio-data of the respondents, while Section B consisted of 28 question items measuring Arabic consonant sounds which constitute pronunciation difficulties for Upper Basic Hausa-speaking students of Arabic Language in Kano State, Nigeria. The pronunciation item was structured along a 5-point Likert-type scale ranging from "Not Difficult Consonant Sound" "Less Difficult Consonant Sound" "Difficult Consonant Sound" "More Difficult Consonant Sound" "Most Difficult Consonant Sound" with a reliability coefficient of 0.75 .

\section{Population and Sampling Procedures}

The population for this study comprised all upper basic Hausa-speaking students of Arabic in Kano State, Nigeria. There are three senatorial districts (i.e. Kano Central, North and South) with the total number of 44 local government areas in Kano State, Nigeria. Two hundred (200) Hausa-speaking students were sampled from the 3 senatorial districts in the state using a multistage sampling procedure. At the $1^{\text {st }}$ stage, simple random sampling technique was used to pick two local government areas from each of the senatorial districts to arrive at 6 local government areas for this study. At the $2^{\text {nd }}$ stage, systematic random sampling was used to select 20 Upper Basic schools across all the 6 selected local government areas in Kano State. At the $3^{\text {rd }}$ stage, purposive sampling technique was used to select Upper Basic III students. This category of students was chosen because they were preparing for their Junior WAEC Arabic Language and thus, at the stage where they are required to be proficient in Arabic pronunciation while at the $4^{\text {th }}$ stage, simple random sampling technique was used to pick ten (10) students from each of the selected schools to arrive at 200 participants as sample size for this study. 


\section{Data Collection and Analysis}

The researchers through two research assistants administered the questionnaire items to all the 'Upper Basic' III Hausa-speaking students. Each student was given a copy of the questionnaire and retrieved immediately since the items could be responded to within 30 minutes. Some were deposited with the teacher and collected a day after. The data gathered were analysed using the following procedures: the data for research questions 1 and 2 were addressed using descriptive statistics (the percentages), while chi square was used to test the hypotheses formulated at 0.05 alpha level.

\section{RESULTS}

\section{Research Question 1:}

What are the Arabic consonant sounds that constitute pronunciation difficulty for the students?

Table 1

Identification and Analysis of Arabic Consonant Sounds Which Constitute Pronunciation Difficulties for Upper Basic Hausa-speaking Students of Arabic in Kano State

\section{Difficulty Level}

\begin{tabular}{|c|c|c|c|c|c|c|c|c|c|c|c|}
\hline 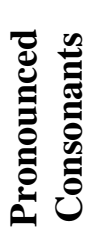 & & NDCS & 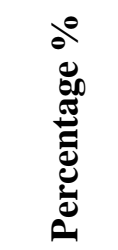 & LDCS & 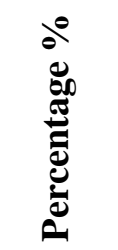 & DCS & 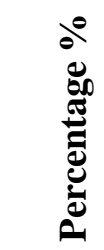 & $\begin{array}{c}\text { More } \\
\text { DCS }\end{array}$ & 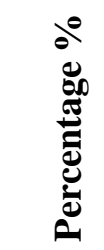 & $\begin{array}{c}\text { Most } \\
\text { DCS }\end{array}$ & 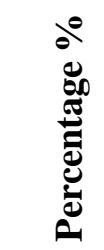 \\
\hline 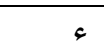 & $/ 2 /$ & 83 & 46.11 & 75 & 4.66 & 8 & 4.44 & 7 & 3.88 & 7 & 3.88 \\
\hline ب & $/ \mathrm{b} /$ & 133 & 73.88 & 40 & 22.22 & 7 & 3.88 & 0 & 0 & 0 & 0 \\
\hline ت & $/ \mathrm{t} /$ & 108 & 60 & 56 & 13.11 & 12 & 6.66 & 3 & 1.66 & 1 & 0.55 \\
\hline 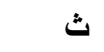 & 47 & 34 & 18.88 & 25 & 13.88 & 18 & 10 & 66 & 36.66 & 37 & 20.55 \\
\hline ج & $/ \mathrm{dz} /$ & 61 & 33.88 & 92 & 51.11 & 17 & 9.44 & 7 & 3.88 & 3 & 1.66 \\
\hline$\tau$ & / f / & 17 & 9.44 & 59 & 32.77 & 34 & 18.88 & 60 & 33.33 & 10 & 5.55 \\
\hline$\dot{\tau}$ & $/ \mathrm{x} /$ & 16 & 8.88 & 61 & 33.8 & 36 & 20 & 48 & 26.66 & 19 & 10.55 \\
\hline 1 & $/ \mathrm{d} /$ & 110 & 61.11 & 53 & 29.44 & 10 & 5.55 & 7 & 3.88 & 0 & 0 \\
\hline$\dot{j}$ & / ठ / & 24 & 13.33 & 31 & 17.22 & 22 & 12.22 & 85 & 47.22 & 18 & 10 \\
\hline J & $/ \mathrm{r} /$ & 96 & 53.33 & 69 & 38.33 & 11 & 6.11 & 3 & 1.66 & 1 & 0.55 \\
\hline j & $|z|$ & 95 & 52.77 & 63 & 35 & 17 & 9.44 & 4 & 2.22 & 1 & 0.55 \\
\hline س & $/ \mathrm{s} /$ & 127 & 70.55 & 40 & 22.22 & 9 & 5 & 3 & 1.66 & 1 & 0.55 \\
\hline ش ش & $/ \int /$ & 116 & 64.44 & 53 & 29.44 & 4 & 2.22 & 7 & 3.88 & 0 & 0 \\
\hline ص & /ș/ & 23 & 12.77 & 38 & 21.11 & 35 & 19.44 & 56 & 31.11 & 28 & 15.55 \\
\hline ض & /d/ & 23 & 12.77 & 33 & 18.33 & 34 & 18.88 & 43 & 23.88 & 47 & 26.1 \\
\hline$b$ & $|t|$ & 25 & 13.88 & 47 & 26.11 & 59 & 32.77 & 44 & 24.44 & 5 & 2.77 \\
\hline ظ & $/ \delta /$ & 19 & 10.55 & 29 & 16.11 & 34 & 18.88 & 67 & 37.22 & 31 & 17.22 \\
\hline$\varepsilon$ & $/ \mathrm{S} /$ & 25 & 13.88 & 58 & 32.22 & 54 & 30 & 37 & 20.55 & 6 & 3.33 \\
\hline$\dot{\varepsilon}$ & / / & 22 & 12.22 & 82 & 45.55 & 57 & 31.66 & 18 & 10 & 1 & 0.55 \\
\hline ف & /f/ & 20 & 11.11 & 39 & 21.66 & 32 & 17.77 & 69 & 38.33 & 20 & 11.1 \\
\hline ق & $/ \mathrm{q} /$ & 35 & 19.44 & 67 & 37.22 & 62 & 34.44 & 15 & 8.33 & 1 & 0.55 \\
\hline 5 & $/ \mathrm{k} /$ & 121 & 67.22 & 41 & 22.77 & 13 & 7.22 & 5 & 2.77 & 0 & 0 \\
\hline$J$ & $/ 1 /$ & 141 & 78.33 & 33 & 18.33 & 6 & 3.33 & 0 & 0 & 0 & 0 \\
\hline
\end{tabular}




\section{Table 1}

Continued

\begin{tabular}{|c|c|c|c|c|c|c|c|c|c|c|c|}
\hline \multicolumn{12}{|c|}{ Difficulty Level } \\
\hline 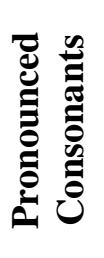 & 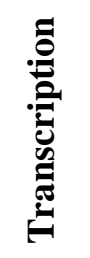 & NDCS & 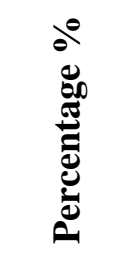 & LDCS & 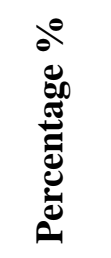 & DCS & 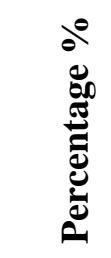 & $\begin{array}{c}\text { More } \\
\text { DCS }\end{array}$ & 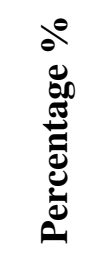 & $\begin{array}{c}\text { Most } \\
\text { DCS }\end{array}$ & 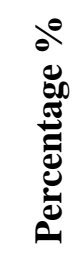 \\
\hline b & $/ \mathrm{m} /$ & 136 & 75.55 & 36 & 20 & 6 & 3.33 & 2 & 1.11 & 0 & 0 \\
\hline ن & $/ \mathrm{n} /$ & 113 & 73.88 & 59 & 32.77 & 6 & 3.33 & 2 & 1.11 & 0 & 0 \\
\hline$ه$ & $/ \mathrm{h} /$ & 80 & 44.44 & 72 & 40 & 19 & 10.55 & 6 & 3.33 & 3 & 1.66 \\
\hline 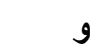 & $/ \mathrm{w} /$ & 138 & 76.66 & 34 & 18.88 & 5 & 2.77 & 1 & 0.55 & 2 & 1.11 \\
\hline ى & /j/ & 113 & 73.88 & 43 & 23.88 & 1 & 5.55 & 10 & 5.55 & 4 & 2.22 \\
\hline
\end{tabular}

Note. Source: Field Survey, 2019

Key:

NDCS: Not Difficult Consonant Sound

DCS: Difficult Consonant Sound

LDCS: Less Difficult Consonant Sound

Most DCS: Most Difficult Consonant Sound

More DCS: More Difficult Consonant Sound

Table 1 indicates that out of the 28 Arabic consonant sounds considered in this study, dhālun, / ð / ( $\dot{\mathbf{j}}$ ) constituted the most difficult sound for the students to pronounce: with 85 $(47.22 \%)$ of the students performing poorly in its pronunciation. Similarly, fāun /f/ (ف) was next in rank with 69 (38.33\%) of the students performing poorly in its pronunciation. Further

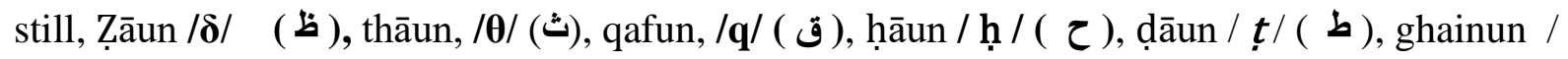
/ ( غ ) and șādun /ș/ (ص) all ranked $3^{\text {rd }}, 4^{\text {th }}, 5^{\text {th }}, 6^{\text {th }}, 7^{\text {th }}, 8^{\text {th }}$ and $9^{\text {th }}$ respectively, with 67 (37.22\%), 66 (36.66\%), 62 (34.44), 60 (33.33\%), 59 (32.77\%), 57 (31.66\%) and $56(31,11 \%)$ of the students performing poorly in the pronunciation of these sounds. Other consonant sounds that constituted pronunciation difficulty for the students include: ' ainun / $/$ / ( $\varepsilon$ ) 54 students (30\%), ḍādun /d/ ( ) 47 students (26.1\%) and khāun /x/ ( غ ) 36 students (20\%). The result of the data analysis revealed that the students used some consonant phonemes to replace others as illustrated below:

1. I was used to replace $\varepsilon$ as there is no corresponding sound for $\varepsilon$ in Hausa

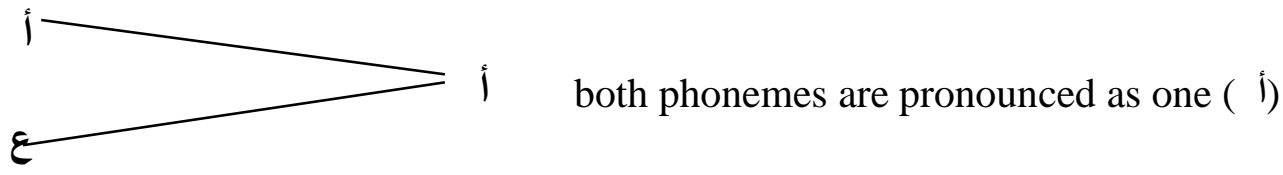

2. $\mathbf{j}$ was used to replace $\dot{j}$ and $\boldsymbol{b}$ because only $j$ has a corresponding sound in Hausa language.

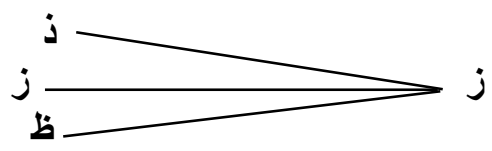


3. 5 was used to replace $\dot{\tau}$ as a result of its absence in Hausa language

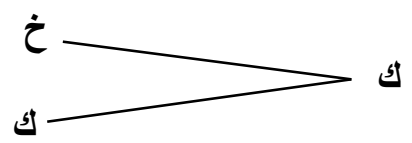

4. س س س س w was was available corresponding phoneme in Hausa language.

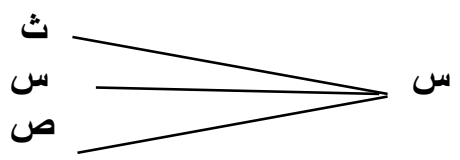

5. $د, J$ and $J$ were used by various students to replace only one phonemically distinctive consonant sound:

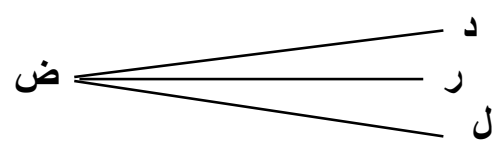

6. Finally, $\bowtie$ was also used to replace $z$ due to the absence of $\tau$ in the Hausa sound system.

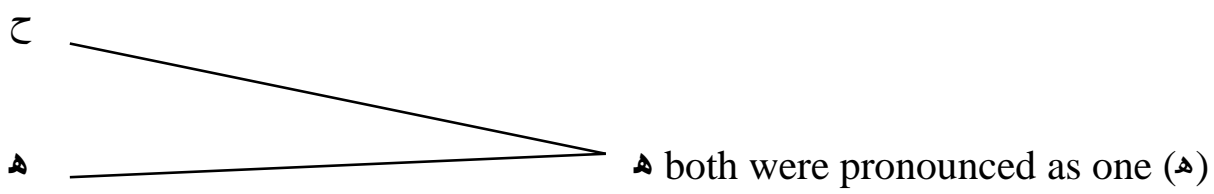

Some phonemically distinctive Hausa consonant sounds were found to be allophones of some other phonemically distinctive Arabic consonant sounds, although, they are not exactly similar but the difference among them is phonetic, not phonemic, i.e., they do not result in changes of meaning. These include:

$\begin{array}{ll}\text { Arabic } & \text { Hausa } \\ \text { b/ț/ } & \text { d /d/ } \\ \dot{\varepsilon} / / & \text { g/g/ } \\ \text { ف/f/ } & \text { f/f/ } \\ \text { ق/q/ } & \text { k /k/ }\end{array}$

Moreover, both Arabic $\mathbf{i}$ and Hausa $\mathbf{f}$ are transcribed as /f/ but it should be noted that native speakers of Hausa language pronounce /f/ as /p/.

Unlike the above listed Arabic consonant sounds that constituted some pronunciation difficulties for the students, the data analysed in the course of this study revealed that sixteen distinctive Arabic consonant sounds did not constitute any pronunciation difficulty for the students due to the presence of their corresponding consonant sounds in Hausa language. These include: 


\section{Research Question 2:}

What are the vowel sounds that constitute pronunciation difficulty for the students?

The responses of the Hausa-speaking students of Arabic to the Pronunciation Test on the vowel sounds were analysed with the use of Descriptive Statistics which involved the frequency counts and the computing of the corresponding percentages as shown below:

\section{Table 2}

Identification and Analysis of Arabic Vowel Sounds which Constitute Pronunciation Difficulties among Upper Basic Hausa-speaking Students of Arabic in Kano State

\begin{tabular}{|c|c|c|c|c|c|c|c|c|c|c|c|}
\hline \multicolumn{12}{|c|}{ Difficulty Levels } \\
\hline $\begin{array}{l}\text { ARABIC } \\
\text { VOWEL } \\
\text { SYMBOL }\end{array}$ & $\begin{array}{c}\text { VOWEL } \\
\text { TRANSLI- } \\
\text { TERATION }\end{array}$ & z & 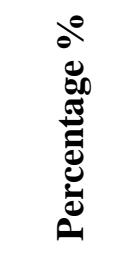 & 先 & 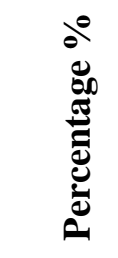 & $\overbrace{}^{\infty}$ & 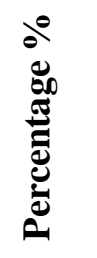 & 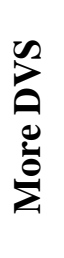 & 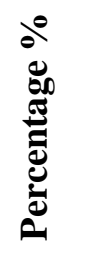 & 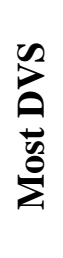 & 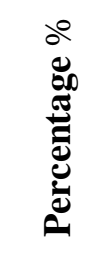 \\
\hline- & $\mathrm{a}$ & 134 & 74.44 & 44 & 24.44 & 1 & 0.55 & 1 & 0.55 & 0 & 0 \\
\hline - & $\mathrm{i}$ & 136 & 75.55 & 38 & 21.11 & 4 & 2.22 & 2 & 1.11 & 0 & 0 \\
\hline- & $\mathrm{u}$ & 128 & 71.11 & 43 & 23.88 & 5 & 2.77 & 3 & 1.66 & 1 & 0.55 \\
\hline $\bar{T}$ & $\mathrm{Aa}$ & 118 & 65.55 & 55 & 30.55 & 4 & 2.22 & 3 & 1.66 & 0 & 0 \\
\hline إي إ & Ii & 112 & 62.22 & 62 & 34.44 & 3 & 1.66 & 2 & 1.11 & 1 & 0.55 \\
\hline أَوْ & $\mathrm{Uu}$ & 108 & 60 & 66 & 36.66 & 1 & 0.55 & 2 & 1.11 & 3 & 1.66 \\
\hline
\end{tabular}

Note. Source: Field Survey, 2019

Key:

NDVS: Not Difficult Vowel Sound DVS: Difficult Vowel Sound

Most DVS: Most Difficult Vowel Sound
LDVS: Less Difficult Vowel Sound More DVS: More Difficult Vowel Sound

Table 2 indicates that six vowel sounds were involved in this study. Field observations revealed that students performed better in vowel sounds. However, long vowel sounds constitute a very little pronunciation problem for the students: /uu/ was a little bit difficult for the students with $2.77 \%$ of them finding it difficult to pronounce while /aa/ and /ii/ also seemed to be a little difficult with $1.66 \%$ each.

\section{Hypotheses Testing}

Hypotheses postulated were tested at 0.05 level of significance.

Hypothesis One: There is no significant difference in the Arabic consonant sounds that constitute pronunciation difficulty for male and female Upper Basic Hausa-speaking students in Kano State. 
Hypothesis One: There is no significant difference in the Arabic consonant sounds that constitute pronunciation difficulty for male and female Upper Basic Hausa-speaking students in Kano State.

\section{Table 3}

Chi - square $\left(X^{2}\right)$ Analysis Showing the Difference in the Arabic Consonant Sounds that Constitute Pronunciation Difficulties for Male and Female Upper Basic Hausa-speaking Students of Arabic in Kano State

\begin{tabular}{lccccccccc}
\hline \multirow{2}{*}{ Gender } & \multicolumn{1}{c}{ Difficulty Levels } \\
\cline { 2 - 11 } & Most DCS & More DCS & DCS & LDCS & NDCS & df & $\chi^{2}$-cal & Sig & Remark \\
\hline Male & 6 & 16 & 15 & 36 & 47 & & & & \\
Female & 3 & 8 & 7 & 15 & 27 & 4 & .707 & .950 & NS \\
Total & 9 & 24 & 22 & 51 & 74 & & & & \\
\hline
\end{tabular}

Note. $\mathrm{p}>0.05$

As shown in table 3 , the $\chi^{2}$-value is 0.707 with a p-value of 0.950 . Since the p-value of 0.62 is greater than 0.05 level of significance, the null hypothesis is maintained. This implies that there is no significant difference in the Arabic consonant sounds that constitute pronunciation difficulty for male and female respondents of Upper Basic Hausa-speaking students of Arabic in Kano State.

Hypothesis Two: There is no significant difference in the Arabic vowel sounds that constitute pronunciation difficulty for male and female Upper Basic Hausa-speaking students in Kano State.

\section{Table 4}

Chi-square $\left(X^{2}\right)$ Analysis Showing the Difference in the Arabic Vowel Sounds that Constitute Pronunciation Difficulties for Male and Female Upper Basic Hausa-speaking Students of Arabic in Kano State

\begin{tabular}{lccccccccc}
\hline \multirow{2}{*}{ Gender } & \multicolumn{9}{c}{ Difficulty Levels } \\
\cline { 2 - 9 } & Most DCS & More DCS & DCS & LDCS & NDCS & Df & $\chi^{2}$-cal & Sig & Remark \\
\hline Male & 0 & 1 & 2 & 34 & 83 & & & & \\
Female & 1 & 1 & 2 & 17 & 39 & 4 & .852 & .583 & NS \\
Total & 1 & 2 & 4 & 51 & 122 & & & & \\
\hline
\end{tabular}

As shown in table 4 , the $\chi^{2}$-value is 0.852 with a p-value of 0.583 . Since the p-value of 0.583 is greater than 0.05 level of significance, the null hypothesis is maintained. This implies that there is no significant difference in the Arabic vowel sounds that constitute pronunciation difficulty for male and female respondents of Upper Basic Hausa - speaking students of Arabic in Kano State. 


\section{Hypothesis Three:}

There is no significant difference in the Arabic consonant sounds that constitute pronunciation difficulties for Upper Basic Hausa-speaking students of Arabic in public and private basic schools in Kano State.

\section{Table 5}

Chi-square $\left(X^{2}\right)$ Analysis Showing the Difference in the Arabic Vowel Sounds that Constitute Pronunciation Difficulties for Upper Basic Hausa-Speaking students of Arabic in Public and Private schools in Kano State

\begin{tabular}{lccccccccc}
\hline & \multicolumn{9}{c}{ Difficulty Levels } \\
Gender & Most DCS & More DCS & DCS & LDCS & NDCS & df & $\chi^{2}$-cal & Sig & Remark \\
\hline Public & 5 & 15 & 13 & 28 & 34 & & & & \\
Private & 3 & 9 & 10 & 23 & 40 & 4 & 2.82 & .588 & NS \\
Total & 8 & 24 & 23 & 51 & 74 & & & \\
\hline
\end{tabular}

Note. $\mathrm{p}>0.05$

As shown in table 5 , the $\chi^{2}$-value is 2.82 with a p-value of 0.588 . Since the p-value of 0.0 .588 is greater than 0.05 level of significance, the null hypothesis is maintained. This implies that there is no significant difference in the Arabic consonant sounds that constitute pronunciation problems for Upper Basic Hausa-speaking students of Arabic in Public and Private Basic Schools in Kano State.

\section{Hypothesis Four:}

There is no significant difference in the Arabic vowel sounds that constitute pronunciation difficulties for Upper Basic Hausa-speaking students of Arabic in public and private basic schools in Kano State.

Table 6:

Chi-square $\left(X^{2}\right)$ Analysis Showing the Difference in the Arabic Vowel Sounds that Constitute Pronunciation Difficulties for Upper Basic Hausa-Speaking students of Arabic in Public and Private schools in Kano State

\begin{tabular}{|c|c|c|c|c|c|c|c|c|c|}
\hline \multirow{2}{*}{ Gender } & \multicolumn{4}{|c|}{ Difficulty Levels } & \multirow[b]{2}{*}{ NDCS } & \multirow[b]{2}{*}{ df } & \multirow[b]{2}{*}{$\chi^{2}$-cal } & \multirow[b]{2}{*}{ Sig } & \multirow[b]{2}{*}{ Remark } \\
\hline & Most DCS & More DCS & DCS & LDCS & & & & & \\
\hline Public & 1 & 1 & 2 & 28 & 63 & & & & \\
\hline Private & 0 & 1 & 1 & 24 & 59 & 4 & 1.22 & .875 & NS \\
\hline Total & 1 & 2 & 3 & 52 & 122 & & & & \\
\hline
\end{tabular}

Note. $\mathrm{p}>0.05$

As shown in table 6 , the $\chi^{2}$-value is 1.22 with a p-value of 0.875 . Since the p-value of 0.0 .875 is greater than 0.05 level of significance, the null hypothesis is maintained. This implies that there is no significant difference in the Arabic vowel sounds that constitute pronunciation problems for Upper Basic Hausa-speaking students of Arabic in Public and Private Basic Schools in Kano State. 


\section{DISCUSSION}

Findings from this study revealed that four phonemically distinctive Arabic consonant sounds were generally the most difficult for Upper Basic Hausa-speaking students of Arabic in Kano State; another four consonant sounds were difficult, while others were less difficult for the students to pronounce. As a result of the pronunciation difficulties associated with some of the Arabic consonant sounds, replacement of sounds occurred as $/ \varepsilon /$ was replaced with / $/$ as in the Arabic word علم / عalamun/ meaning "a flag" which was wrongly pronounced as / 'alamun / meaning "pain”. Two phonemically distinctive Arabic consonants $\mathbf{j} / \boldsymbol{\delta} /$ and $\boldsymbol{b} / \delta /$ were replaced by a single Arabic phoneme $\mathrm{j} / \mathrm{z} /$ which has z /z/ as its corresponding phoneme in Hausa. Thus,

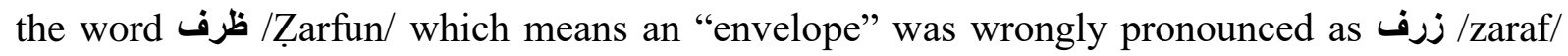
which is meaningless in Arabic. Likewise, the word ذرة /dhuratun/ meaning "maize" was wrongly pronounced /zuratun/ by replacing $/ j /$ with $/ \dot{j} /$, thereby rendering the word meaningless. The Arabic consonant $\dot{\tau} / x /$ was wrongly replaced with $5 / k /$ as in the Arabic word خزانة (khizānatun) meaning “a cupboard.” This was wrongly pronounced as /kizanatun/ where $\dot{\tau} / \mathrm{x} /$ is substituted with $s / \mathrm{k} /$ and thereby rendering the word meaningless. Two other Arabic consonant phonemes $ث / \theta$ / and $/$ /ṣ/ were also replaced with one Hausa consonant phoneme س /s/ as in the word ثلاجة/Oallādzatun/ meaning "refrigerator" which was wrongly pronounced as /sallādzatun/ which is meaningless in Arabic, and the word صندوق/șunduqun/ meaning "a box" which was wrongly pronounced as سندوق /sunduqun/ which is meaningless.

Also, the Arabic consonant phoneme ض /d/was wrongly replaced with three phonemically distinctive alternative Arabic consonant sounds which have Hausa equivalents. The replacement was done by various individual students. For example: the word ضمام /dammam/ meaning "paper fastener" was wrongly pronounced in three different ways: (i) /dammam/ with $د / \mathrm{d} /$ meaning "a painter"; (ii) /rammam/ with $\lrcorner / \mathrm{r} /$ meaning "repairer" (iii) /lammam/ with J/I/ meaning "spearmint". The consonant phoneme $\tau$ / $/$ / was replaced with an alternative phoneme /h/ as in the word حقائب / كaqā̄ib/ meaning "bags." This was pronounced wrongly as /haqa'ib/ which has no meaning in Arabic language. The above are the Arabic consonant phonemes that constituted pronunciation difficulties for Upper Basic Hausaspeaking students of Arabic in Kano State because they do not exist in Hausa language. This finding corresponds with the finding of Al-Janariy (2008) and Hamza (1998) who noted that there were phonological problems facing students of Arabic in West Africa, including native speakers of Hausa.

Findings from this study revealed that Arabic vowel sounds did not constitute pronunciation difficulties for the Upper Basic Hausa-speaking students of Arabic in Kano State. This could be due to the fact that the entire Arabic short and long vowel sounds as well as the Arabic diphthongs have approximately similar sounds in Hausa language. Anyway, Arabic short vowels were occasionally prolonged while the long vowels were sometimes shortened by the research subjects. This was discovered to be the problem of phoneme recognition but not that of sound production (Field Survey, 2012). 
Furthermore, the Arabic primary vowels, fathah, kasrah and dummah, indicated in tables 1 and 2, were mistakenly interchanged by the respondents. The research subjects occasionally replaced fatha sound with kasrah or dumma; and at times dummah with kasrah or fathah, or the other way round. Nevertheless, this pronunciation misappropriation was found to be a vowel recognition problem but not actually the problem of vocalisation of the vowel sound per se (Field Survey, 2012). These findings correspond with the research results of Oladosu (1992), Hamza (1998) and Adebayo (2010) who inferred that Arabic vowel sounds do not constitute pronunciation problems for the students.

This study shows that there was no significant difference in the Arabic consonant and vowel sounds that constitute pronunciation problems for male and female respondents of Upper Basic Hausa-speaking students of Arabic in Kano State. This result corresponds with the findings of Amadi (2010) and Adebayo (2010) who, among others, found that there was no gender difference in the academic performance of students. This finding, however, disagrees with the assertion of Larsen-Freeman \& long (1991) who found that females were better than males in both first and second language acquisition.

This study also revealed that irrespective of the types of school attended by the Upper Basic Hausa-speaking students of Arabic in Kano State, there was no significant difference in the Arabic consonant and vowel sounds as well as the Arabic syllable patterns that constituted pronunciation difficulties for the students. The results of the hypotheses testing showed that there was no significant difference in the consonant and vowel sounds as well as the syllable patterns that constitute pronunciation difficulties for Upper Basic Hausa-speaking students of Arabic in public and private Upper Basic schools in Kano State. These findings agree with the finding of Adebayo (2010) who found no significant difference in the Arabic consonant and vowel sounds that constitute pronunciation problems for students of Arabic from Federal Government Colleges (treated like private schools) and students of Arabic from other public secondary schools.

\section{CONCLUSION}

It can therefore be concluded that out of the 28 phonemically distinctive Arabic consonant sounds, 16 distinctive Arabic consonant sounds did not constitute any pronunciation difficulty for the students due to the presence of their corresponding consonant sounds in Hausa language which include س ش remaining 12 constituted pronunciation difficulties for Hausa-speaking Students of Arabic in Kano State: four (4) were the most difficult for the students to pronounce. These include: ذ and the other 4 constituted a less pronunciation difficulty for the students: ق ف غ

All of the Arabic vowel phonemes did not constitute pronunciation difficulties for Upper Basic Hausa-speaking students of Arabic in Kano State as the vowel phonemes have corresponding vowel sounds in Hausa language. Meanwhile, there was no significant 
difference in the Arabic consonant and vowel sounds that constitute pronunciation difficulties for male and female Upper Basic Hausa-speaking students of Arabic from both public and private schools in Kano State.

\section{RECOMMENDATION}

Based on the findings obtained from this study, it was thus recommended among others, that teachers of Arabic language should pay more attention to the various Arabic consonant and vowel phonemes as well as the Arabic syllable patterns that constitute pronunciation difficulties for the Hausa-speaking students of Arabic. The attention of Hausa-speaking students of Arabic should be drawn to the semantic implications of phonemic replacement, reduction or prolongation. In this regard, teachers of Arabic language should employ the use of modern materials and resources for teaching/learning of Arabic such as Arabic recorded sounds on tapes and CD/DVD disc/plates; Arabic instructional media; computer as well as the Arabic language learning programmes, films, movies, the satellite and the internet.

Textbook's writers should use the findings of this research to identify and lay more emphasis on the areas that generate pronunciation difficulties for the students of Arabic. Here, it should be noted that classroom experience proves that, textbooks produced and accompanied by tape recorded sound and films for demonstration and illustration facilitate better learning. In a nutshell, more relevant modern Arabic phonology textbooks should be produced. Curriculum developers, in any future curriculum review, should take into consideration, the findings of this research work with respect to oral Arabic, selection of curriculum content, learning experience, grading and presentation. 


\section{REFERENCES}

Abdallah, A. S. (2005). The Arabic sounds system and teaching pronunciation. London: School of Oriental and African Studies (SOAS).

Abdelali, E. (2003). Arabic language in sub-saharan Africa: Past, present and future. Retrieved from http://www.isesco.org.ma/english/publications /Islamtoday/20/p6.php.

Adebayo, A. (2010). Pronunciation problems among Yoruba-speaking students of Arabic in Ilorin, Nigeria. An unpublished M. Ed Research Project. Ilorin: University of Ilorin, Ilorin.

Al-janariy, S. B. (2008). Phonetic errors in the Qur'anic recitation of some selected university students in Nigeria: An analytical study. In Z. I. Oseni (Ed.), "Florescence of Arabic and Islamic Studies in Nigeria” (Festschrift in honour of Prof. Wahab O.A. Nasiru). Ibadan: HEBN Publishers Plc.

Al-Saidat, E. M. (2010). Phonological analysis of English phonotactics: A case study of Arab learners of English. The Buckigham Journal of Language and Linguistics,3.

Awagona, A., Löhr, D. \& Wolff, H.E. (2009). Loanwords in Hausa: Chadic language in West Africa. Retrieved from Walter de Gruyter Reference Gloval: http://www.referencegloval.com

Badamasi, U. B. (2012). A Comparative Study of Educational Investment for Human Capital evelopment Between Southern and Northan Nigeria: A case study of Kano and Lagos States. A working paper. Retrieved on $28^{\text {th }}$ July 2012. www.academia.edu.

Federal Republic of Nigeria (2004). National policy on education ( $5^{\text {th }}$ edition). Yaba- Lagos: NERDC Press, Nigeria.

Federal Republic of Nigeria (2013). National policy on education and 4-year strategic plan for the development of the education sector: 2011-2015 of professor Ruqayyatu Ahmed Rufa'i. NERDC Press, Yaba- Lagos: Nigeria.

Micheal, R. \& Gwyneth, F. (2007). Macmillan English Dictionary: International student edition. Malaysia: A \& C Black Publishers Ltd.

Musa, S. \& Abdullahi, M.S. (2017). Pronunciation difficulties in Arabic syllable patterns among upper basic Hausa-speaking students in Kano state, Nigeria. The Springboard Journal 9 (1).

Oladosu, A. G. A. S. (2002). Eclecticism in language teaching application to Arabic education in Nigerian schools. In A. Lawal, I. Isiugo-Abanihe, \& I. N. Ohia (Eds.), Perspectives on applied linguisitcs in language \& literature ( $1^{\text {st }}$ ed., 323-333). Ibadan: Stirling-Horden Publishers (Nig) Ltd.

Oladosu, A.G. A. S. (2012). Fluctuations in the fortunes of Arabic education in Nigeria. The one hundred and fifteenth $\left(115^{\text {th }}\right)$ Inaugural lecture. Ilorin. Unilorin Press.

Senel, M. (2006). Suggestion for beautifying the pronunciation of ELF learners in Turkey. Journal of language and linguistic studies, 2 (1). 
Clayson, D. E., \& Haley, D. A. (2005). Marketing models in education: Students as customers, Trask, R.L. (1996). What is pronunciation? New York: Routledge.

ULC. (2010). Language material project (Arabic). University of California consortium for language learning and teaching (Davis, CA). Retrieved from http://www.imp.ulc.edu/profile.aspx? Lang. 